\title{
Analysis of Foreign Classical Policy Tools for Strategic Emerging Industries-Government Procurement and Subsidy Policies
}

\author{
Xu Guannan ${ }^{1}$, Wang Xiuqin ${ }^{2}$, Pan Meijuan ${ }^{2}$, Zhou Yuan $^{2}$ \\ 1. School of Economics and Management, Beijing University of Posts and Telecommunications, Beijing 100876, China \\ 2. School of Public Policy and Management, Tsinghua University, Beijing 100084, China
}

\begin{abstract}
Strategic emerging industries are currently the key to upgrading a country's industrial structure and gaining international competence. Countries all over the world consider the development of strategic emerging industries as a national strategy and apply various policy tools to promote the development of such industries vigorously. Therefore, research on the important measures adopted internationally to promote the development of strategic emerging industries can offer an important reference point for China to implement relevant emerging industry policies. This paper mainly analyzes two classical policy tools adopted by developed countries, including the government procurement and government subsidies, so as to provide reference for China to cultivate and develop its strategic emerging industries.
\end{abstract}

Keywords: emerging industry; policy tools; government procurement; government subsidy; industrial policy analysis

\section{Introduction}

A new scientific and technological revolution is about to break out as developed countries begin promoting a strategy of "re-industrialization." Strategic emerging industries have become the key to upgrading a country's industrial structure and seizing the commanding height of the world economic development [1]. China's strategic emerging industries have recently made great progress, providing powerful support for their role in leading the economic and social transitions of China. To ensure healthy and sustainable social and economic development and implement an innovative-driven development strategy, China must also further adopt effective measures to cultivate a batch of strategic emerging industries, accelerate the formation of new growth points, promote an upgrade to the economic structure, and improve international competitiveness.
Various countries have realized the significance of strategic emerging industries in taking the lead in cutting-edge technologies and enhancing national competitiveness. Therefore, many countries have elevated the development of emerging industries to the national policy level. Aiming at industries that have huge growth potential and offer comprehensive benefits, such as new energy, biological pharmacy, information infrastructure, and new energy automobiles, these countries promote the development of emerging industries by making development plans, applying various policy tools, and comprehensively enhancing government support. Researching the important measures adopted by other countries to develop emerging industries provides an important reference value for China to implement relevant policies. This study mainly analyzes two classical policies of government procurement and government subsidies to provide a reference for China to cultivate and develop its strategic emerging industries.

Received date: 30 May 2016; revised date: 12 July 2016

Author information: Xu Guannan, School of Economics and Management, Beijing University of Posts and Telecommunications, assistant professor. Her current research is technological innovation and industrial policy. E-mail: xuguannan@139.com

Foundation item: Project of the National Natural Science Foundation of China (No. 71303130, 71203117, L1524015, 71233005); Chinese Academy of Engineering Important Fund Subject of Research on the Cultivation and Development Planning of China's Strategic Emerging Industry in the 13th Five-Year Plan Period (No. 2014-ZD-7); Sub-project of Green Economy and Sustainable Development Research Center of Tsinghua University (No. 20153000181)

Chinese version: Strategic Study of CAE 2016, 18 (4): 113-120

Cited item: Xu Guannan et al. Analysis of Foreign Classical Policy Tools for Strategic Emerging Industries--Government Procurement and Subsidy Policies. Strategic Study of CAE, http://10.15302/J-SSCAE-2016.04.017 


\section{Overview of policy tools to promote the development of strategic emerging industries}

Developed countries adopt various policy tools to cultivate and develop emerging industries, encourage innovations at rising enterprises, create a successful market environment, and guide and promote development of these emerging industries to create an international competitive advantage.

Policy tools include various measures, strategies, methods, technologies, mechanisms, actions, human resources, equipment, and other resources and means that are carried out to realize certain policy objectives [2]. The policy tools for promoting the development of emerging industries have different characteristics. Overall, they can be divided into three categories: supply policy, environmental policy, and demand policy [3-5]. Of these, supply-type policy tools drive scientific and technological activities, meaning that the government directly expands its technological supply, promotes technological innovation and new product development through talent, capital, technology, and public services. Environmental policy tools are those environmental factors that influence scientific and technological development, in which the government influences the environmental factors of scientific and technological development through planning, financial support, preferential taxation, legal governance, property rights, and other related policies to indirectly influence and promote scientific and technological innovations and new product development. Demand-type policy tools are those that reduce the market's ambiguity through government procurement, trading policies, users' subsidies, application demonstration, price guidance, and other measures that actively expand and maintain a stable market for applying new technology to drive technological innovations and new product development [6-8].

Most developed countries tend to support innovative development in emerging industries through government procurement, preferential taxation, user subsidies, financial support, government planning, international trade, and other means. Among these, government procurement and government subsidies are the two most traditional industrial policy tools. This paper will mainly discuss how developed countries adopt these two policies to cultivate and develop emerging industries.

\section{Analysis of government procurement policies}

\subsection{Overview of government procurement}

Government procurement refers to government purchases of specific products and technology on a large scale to create relatively stable market expectations, reduce the market's ambiguity, and inspire enterprises to pursuit innovation. This includes procurement by the central government, local governments, and public institutions. Government procurement includes purchases of innovative products and sponsoring research and development
(R\&D). The government can promote technological innovation either by direct procurement of products or by purchasing new technologies. At present, government procurement is a powerful means adopted by many countries to regulate economic functions, address national strategic intentions, and promote technological innovations. It is also an important policy tool to support enterprises' innovations in China from the demand perspective, which plays an important role in promoting emerging industries' innovative development [9].

Technological innovation covers a range of process from new hypotheses to research, development, trial formulation, production and manufacturing, and then to the first commercialization [10]. Market adoption of innovative achievements is an extremely important link. Generally, the government procurement role in technological innovation typically occurs in three ways: first, government procurement can create a special "government market" to stimulate the market demand in the initial phase of technological innovation, leading the development of major technology; second, according to national strategic demand, government procurement can offer macroscopic guidance to technological innovations through negotiation with the suppliers and specific requirements for performance and specifications of purchased goods, as well as the selection of the technical projects that are to be developed based on its priorities; third, the risks and high costs of innovation are important obstacles. The government procurement market can act as the experimental field for products from technological innovation, which can provide indirect support to the eventual link of innovative activities, shouldering the risks of technological innovations, so that scientific achievements with development prospects can complete the innovation and development processes, despite lacking market acceptance [11]. Table 1 summarizes various governments' procurement processes.

\subsection{Evolution of developed countries' government procurement policies}

Developed countries usually pay more attention to promoting technological innovation through government procurement. Consequently, the procurement of high-tech products plays an important role in promoting economic development. The US is the first country to successfully adopt policy procurement to promote innovation and to develop its emerging industries. In particular, the US government established crucial procurement policies to support and promote the development of the electronics, semi-conductor, computer, and other related industries [13]. In the initial phase of developing integrated circuits, from 1960s to 1970 s, for example, the government procurement accounted for $94 \%$ of product purchases. The US government's procurement of advanced technology accelerated the process through which enterprises' technological innovations were developed, turned into commodities, and ultimately industrialized. It also triggered the quick emergence of Silicon Valle and later the No.128 Road 
Table 1. Government procurement process [12].

\begin{tabular}{|c|c|c|c|c|c|c|}
\hline Process & & Deficiencies addressed & & Instrument types & & Examples \\
\hline Framework conditions & ii) & $\begin{array}{l}\text { Procurement regulations } \\
\text { driven by competition logic } \\
\text { at the expense of innovation } \\
\text { logic. } \\
\text { Requirements for public } \\
\text { tenders unfavorable to small- } \\
\text { and medium-sized enterprises } \\
\text { (SMEs) }\end{array}$ & i) & $\begin{array}{l}\text { Introduction of } \\
\text { innovation-friendly } \\
\text { regulations } \\
\text { Simplification and } \\
\text { easier access for tender } \\
\text { procedures }\end{array}$ & i) & $\begin{array}{l}\text { Changes of European Union (EU) Directives in } \\
\text { 2005, including functional specifications, negotiation } \\
\text { procedure, etc. } \\
\text { The EU proposal of introducing innovation } \\
\text { partnerships in } 2011 \\
\text { The paperless procedures and procurement target of } \\
\text { electronic orders to increase the SMEs' share }\end{array}$ \\
\hline $\begin{array}{l}\text { Organization \& } \\
\text { capabilities }\end{array}$ & ii) & $\begin{array}{l}\text { Lack of awareness of } \\
\text { innovation potential or } \\
\text { innovation strategy in } \\
\text { organizations } \\
\text { Procurers lack skills } \\
\text { in innovation-friendly } \\
\text { procedures }\end{array}$ & i) & $\begin{array}{l}\text { High level strategies with } \\
\text { innovation procurement } \\
\text { embed in } \\
\text { Training schemes, } \\
\text { guidelines, good practice } \\
\text { networks } \\
\text { Subsidies for the } \\
\text { additional costs of } \\
\text { innovation procurement }\end{array}$ & i) & $\begin{array}{l}\text { Innovation Procurement Plans 2009-2010 for British } \\
\text { government } \\
\text { the Netherlands PIANO supports network, EU lead } \\
\text { the public sector to participate in Market Initiative } \\
\text { Finnish Funding Agency for Innovation (TEKES) } \\
\text { meets the } 75 \% \text { costs in procurement planning stage; } \\
\text { European Commission gives } 30 \% \text { of the financial } \\
\text { cost to the purchasing department of actively sharing } \\
\text { the bidding experience }\end{array}$ \\
\hline $\begin{array}{l}\text { Identification of } \\
\text { specification and } \\
\text { requirements }\end{array}$ & ii) & $\begin{array}{l}\text { Lack of communication } \\
\text { between end users and the } \\
\text { government responsible for } \\
\text { procurement } \\
\text { Lack of knowledge and } \\
\text { organized discourse about } \\
\text { the purchasers' innovation } \\
\text { potential }\end{array}$ & ii) & $\begin{array}{l}\text { Adopt pre-commercial } \\
\text { procurement (PCP) of } \\
\text { research and development } \\
\text { (R\&D) to develop and } \\
\text { demonstrate } \\
\text { Set up innovation } \\
\text { platforms, conduct market } \\
\text { research, use standards } \\
\text { and certification of } \\
\text { innovation }\end{array}$ & i) & $\begin{array}{l}\text { Small Business Innovation Research (SBIR) } \\
\text { program: USA, Australia; SBRI and PCP: UK } \\
\text { Innovation Partnerships \& Market Initiative, } \\
\text { Innovation Platforms (UK) }\end{array}$ \\
\hline $\begin{array}{l}\text { Incentivizing } \\
\text { innovative solutions }\end{array}$ & ii) & $\begin{array}{l}\text { Bearing risk from innovation } \\
\text { procurement } \\
\text { Procurer risk aversion }\end{array}$ & ii) & $\begin{array}{l}\text { Calls for tender required } \\
\text { innovation; guaranteed } \\
\text { purchase or certification } \\
\text { of innovation; guaranteed } \\
\text { price/tariff concessions for } \\
\text { innovation } \\
\text { Security guarantees }\end{array}$ & i) & $\begin{array}{l}\text { German law enabling innovation demands in tenders; } \\
\text { UK forward commitment procurement } \\
\text { immunity and certification scheme (Korea) }\end{array}$ \\
\hline
\end{tabular}

High-tech Industrial Belt. Meanwhile, in the initial phase of the 1970s, the US government implemented experimental initiative technical plans, and the Federal Standard Bureau, together with the Scientific Fund Commission, stimulated the participation of an industrial circle in developing and researching projects by government procurement. They also clearly proposed specific guidelines promoting technical innovations [14].

Besides the US, developed countries in Europe also pay more attention to adopt procurement policies to promote enterprises' innovations. In 2004, the French, German, and UK governments submitted a report on constructing an innovative Europe, which suggested that Europe should adopt government procurement policies to stimulate innovations. The report proposed creating an innovation and friendly market and taking actions to create a harmonious system and rule, ambitious standards application, a competitive intellectual property system, and public procurement system that drives demand. In 2006, the European Commission published documents on strategic innovation policies, paying greater attention to the important role of public procurement played in the development of innovations and an innovative market. The EU proposed adopting of PCP as a policy tool to promote innovations [15], in which public procurement departments sign long-term contracts and make commitments with suppliers to provide commodities or services in the future according to a preset effectiveness level and costs before the innovative products are manufactured or commercialized on a large scale. This procurement procedure is usually divided into three phases: feasibility analysis, product research and trial production, and application testing. As time goes on, the number of suppliers will gradually diminish in competitive process, but in the third phase, there should be a minimum of two suppliers to ensure the competitiveness of the future market, which reflects the mechanism about embedded competition promoting innovation [11].

Among other research, studies on Finland's innovative commercialization show that $48 \%$ of successful innovative projects benefit mainly from public procurement. Finland, France, and other EU countries divide government procurement of technology into the procurement of developmental technology and accommodating technology to support the adoption of different procurement means and procurement contracts [9]. The Czech Republic's government procurement fees in 2013 were 475 billion CZK, accounting for $12 \%$ of its GDP. Since 2010, the proportion of the Czech Republic's government procurement in GDP has been decreasing, mainly due to austerity policies [16]. 


\subsection{Government procurement case in developed countries}

A case of the UK PCP expounds on this government's procurement process to promote SEMs' technological innovations and the policy of how to promote innovative development of emerging industries.

To solve the challenge faced by the government and other public departments, it is necessary to strengthen awareness of R\&D's fundamental role in future business interests. In 2011, the UK Technology Strategy Board proposed the Research Plan for Small Enterprises' Innovations. The UK Technology Strategy Board was established and sponsored by the UK Department for Business, Innovation, and Skills. It is a business-led and nondepartmental public body, and its main function is to promote R\&D and technical innovation and application to benefit UK enterprises. The Research Plan for Small Enterprises' Innovations was launched by the Technology Strategy Board to promote UK innovations.

One of the innovations promoted in this plan was "Causing the trend: System of communicating through gestures" launched on January 10, 2011. This innovation was designed to help the disabled or learners with communication impairment to communicate using mobile equipment [15].

This project was completed in two phases: the first phase tested concepts, which was used to test the practicability of the technology. The plan's fund covered the first phase (six months at most), with an overall expenditure of 250000 GBP. The second phase covered development and promotion and mainly used the technological innovation produced in the first phase for promotion and demonstration. The project included 11 evaluation standards in all, which ranged from offering free and open resource software models to selecting companies to test practicability, technology stability, and expenditure effectiveness. The time node to submit the plan proposal was March 12, 2011 with a cycle of two months, which showed that the government wanted applicants to offer quick feedback. The contract date for successful applicants was April 21, 2011, and solution plan's feasibility report was required to submit before October 28, 2011.

In the first phase, three enterprises received with capital support and were strictly supervised and evaluated over a period of time, while two companies (Gamelab Ltd. and Technabling Ltd.) successfully moved to the second phase. Based on the Microsoft's Kinect technology, Gamelab developed a gesture recognition procedure (Ukinect), while the Technabling developed the "portable gesture translator" to help people who speak through gestures to translate those gestures into words. This is a convenient, flexible, and formulated solution. These two-hand gesture recognition demonstration projects can help people with language impairments to communicate with others through portable equipment.

The present thinking is that both Ukinect and the portable gesture language translator can be applied in the educational and social fields, so this project represents a high market potential. Currently, these two companies still devoted to improving their technology to cover all English gesture languages and to develop existing prototypes into mature products that are affordable for common consumers.

\section{Analysis of government subsidy policies}

\subsection{Overview of government subsidies}

From a macroscopic perspective, the government subsidy policy tool mainly includes preferential taxation, financial subsidies, and demand-side support.

\subsubsection{Preferential taxation}

The mode of preferential taxation is varied and mainly includes treatment for enterprise revenue tax, exemptions to and reductions of business tax, individual income tax, estate tax, and stamp duty. Specifically, the direct preferential for enterprise revenue taxation includes exemption from and reduction in taxes; and indirect enterprise preferential taxation includes tax deductions, reserve funds, and tax credits. Implementing preferential taxation for advanced technology and new energy industries help to expand the scale of technical R\&D and re-innovations among enterprises, and to improve their technical innovation ability and resource efficiency.

\subsubsection{Financial subsidy}

Generally, financial subsidies mainly involve price subsidies. There are two major hurdles to implementing price subsidies: subsidy subject (manufacturer and consumer) and subsidy standards (regulations on subsidy proportion). Offering a subsidy to manufacturers can help stimulate them to expand their production scale and increase investment to decrease costs and increase benefits. Offering a subsidy to consumers aims to improve consumer consumption demand and space. Especially for a new energy product, a price subsidy can expand the space for consumers to select it and expand its market share, thereby to promote the market promotion of new energy and new technology products.

\subsubsection{Supply-side support}

For supply-side support, the government offers policies support to new energy industries in terms of capital, land, equipment, and other production elements. Capital support takes on many forms, such as funds for scientific research, capital rewards, credit interest subsidies, and the establishment of special venture funds. Through production support, the government can strengthen the construction of technical facilities, reduce technical risks in the industrial development process, solve new energy industry bottlenecks in terms of capital, technology, land, and 
other fundamental elements, and improve the degree of technological innovation.

In the development process of emerging industries, enterprises tend to face external and internal ambiguity from the technology, the market, and policies. Technical risks apply to the ambiguity of the technical environment and the technology itself, while market risks refer to the ambiguity of the consumer structure, their preferences, differences, scale, and the strength of the competition [17]. These risks tend to be more significant in development process for emerging industries. Thus, government subsidy and supporting polices can reduce the internal and external risks that such industries face during their development and promote the future development of emerging industries.

Generally, government subsidies have several main in the development of emerging industries: firstly, a government subsidy adjusts emerging industries' supply structures by lowering production costs, expanding production scales, increasing profits, and increasing the product supply. Secondly, government subsidies may cause an adjustment to the demand structure of emerging industries. Through a price subsidy for consumers, the government will increase the probability that consumers select new energy products, for example, and thereby improve their consuming ability to consume these products and thus influence the demand structure. Moreover, government subsidies internalize the external effect. For example, input into the R\&D and innovation government subsidy polices can make up their external effect and internalize them [18].

\subsection{Evolution of government subsidy policies in developed countries}

This section concentrates on government subsidy policies for new energy industries, which can provide the reference for the subsidy policies of other emerging industries and universal government subsidy policies in China.

EU countries mainly focus on four aspects in their policies for offering subsides for new energy. First, these countries offer price incentives by formulating reasonable feed-in tariffs for new energy power. Second, they invest in subsidies, which for new energy involve several fields such as photovoltaic power generation, biomass energy, and wind power. These subsides have the characteristics of being large and long lasting. Third, the tax policies mainly focus on collecting heavy taxes targeting fossil energy consumption and implementing tax-free policies targeting renewable energy application. For example, the EU exempts fuel taxes on bio-fuel to promote the development of liquid bio-fuel. Finally, governments may implement a quota system by constructing a "green power certificate" trading market sot that new energy flows in the market.

German adopted a fixed feed-in tariff policy before 2011. The development of Germany's renewable energy has shifted recently to a model of "limited government support + participation in market competition." It has also become the first country to cancel subsidies for new energy electricity. As of 2017, Germany's renewable energy will no longer enjoy a fixed feed-in tariff subsidy. Instead, it will adopt an auction and use a negotiated price network mechanism.

The UK has implemented a renewable energy compulsory system and combined it with contract for difference (CfD) fixed electricity fee policies. Since 2014, power generators with more than $5 \mathrm{MW}$ can choose between the quota system and the CfD fixed electricity fee policies. After 2017, it will no longer have quota system policies but instead formulate carbon floor prices (CPF) and energy performance standards (EPS) to control greenhouse gas emissions.

In Denmark, the renewable energy feed-in tariff includes policies targeting market prices and premium subsidies. Denmark also stipulates that part of small-sized renewable energy systems are exempted from public service obligation (PSO) and the large-scale renewable energy resource system implements tax reduction policies.

The Netherlands introduced a new subsidy plan, Stimulering Duurzame Energie, between 2008 and 2011. This plan controls the sum of overall subsidies to various renewable energy resources and selects projects to implement fixed subsidies through bidding. In line with the prices of fossil energy, it formulated subsidy standards and estimated various load capacities between 2008 and 2011. In 2008 and 2009, however, maritime wind power was not within the subsidy range. In 2011, the Netherlands published the "SDE+" policy, which adjusted the subsidies for electricity prices of various renewable production costs. Following the first come, first served principle, it set electricity subsidy values of $0.09,0.11,0.13$, and 0.15 EUR per kilowatt hour. Meanwhile, it established a fund for renewable energy investment to provide loans, preferential financing and other services targeting renewable energy.

To encourage the development of wind power and other renewable energy technology, France has largely adopted feedin tariffs and introduced the Energy Policy Method Determining the Positioning of Energy Policies, which established the basic direction of French energy policies in the future; namely, promoting the diversification of the energy supply, increasing the ratio of renewable energy consumption, increasing research in the energy industry and innovative development, providing the reserving means of energy transportation to guarantee the quality of the power supply to ensure a safe energy supply.

Thus, it appears that developed countries offer huge subsidies for new energy industries with diverse subsidy models .

\subsection{Government subsidy cases}

As is shown in Table 2, this section examines the new energy automobile industry as an example and summarizes the direct subsidy policies in some developed countries. 


\section{Conclusions and implications}

This study analyzes the policy tools that various countries have adopted to develop emerging industries, especially, the government procurement and government subsidy tools. From this, the following implications can be seen:

(1) Governments should adopt a portfolio of policy tools to promote the development of emerging industries from multiple perspectives

The realization of innovations comes from a package of

Table 2. Policies and standards of government subsidies for the new energy automobile industry [19].

\begin{tabular}{ll}
\hline Country & Policies and standards of specific subsidies for new energy automobiles \\
\hline US & A nationwide subsidies for new energy automobiles sold after November 31,2008 , and the tax is reduced by between 2500 and 7500 \\
& US dollars according to the battery's capacity. The first 200000 new energy automobiles sold by each automobile manufacturer \\
can all enjoy the above preference. In March 2014 , the White House planned to raise subsidies nationwide to make the new energy \\
automobiles enjoy a tax preferential treatment of 10000 US dollars. However, such benefits do not apply to luxury brands
\end{tabular}

Germany It exempts tax but offers no subsidies. Its stimulus initiative are as follows: new automobiles bought between May 2011 and December 2015 can enjoy a 10-year exemption from motor vehicle tax; new automobiles bought between January 2016 and December 2020 can enjoy a 5-year exemption, and they can share a car license plate with another vehicle in the home to save insurance fees. In theory, a new energy automobile weighing $1500 \mathrm{~kg}$ in Germany should pay a motor vehicle tax of 45 EUR

Austria According to the specific situations of each state, Austria formulated relevant subsidy measures. For example, 1) Burgenland offers a subsidy up to 750 EUR to purchase an electric automobile and 2) Niederösterreich offers a subsidy of up to 2000 EUR to purchase a battery electric vehicle (BEV). If the electricity to charge the car comes from renewable energy, the subsidy increases to 3000 EUR. The government offers a subsidy of up to 1000 EUR to owners purchasing a plug-in hybrid electrical automobile. If the electricity to charge the vehicle comes from a renewable energy source, the subsidy increases to 1500 EUR. 3) Other states offer no subsidy for electrical vehicles for private use

France $\quad$ For automobiles with carbon dioxide emissions of less than $20 \mathrm{~g} \cdot \mathrm{km}^{-1}$, the government offers a subsidy of 7000 EUR in the first phase. The subsidies targeting these automobiles should not exceed $30 \%$ of the automobile's price (including value-added tax). For automobiles with a carbon dioxide emission of $20-50 \mathrm{~g} \cdot \mathrm{km}^{-1}$, the subsidy is 5000 EUR. For hybrid electric automobiles with a carbon dioxide emission of less than $110 \mathrm{~g} \cdot \mathrm{km}^{-1}$, the subsidy is 3300 EUR

Additionally, the government also plans to improve the subsidy range substantially. For example, when purchasing an electric automobile to replace an original diesel one, the car owner will receive another subsidy of 10000 EUR in addition to the existing subsidy of 6300 EUR

Norway In Oslo, buying electric automobiles can exempt people from $25 \%$ of the value-added tax and import tariff. The road maintenance fees will also be exempt in 2017. In some parking lots, people can also enjoy free charging

the Netherlands Electric vehicles are exempt from registration tax. Hybrid electric vehicles with diesel hybrid power emitting less than $85 \mathrm{~g} \cdot \mathrm{km}^{-1}$ of carbon dioxide are also exempt from registration tax, while the limit for gas hybrid electric vehicles is $88 \mathrm{~g} \cdot \mathrm{km}^{-1}$. For all vehicles, automobiles that emit less than $0.5 \mathrm{~g} \cdot \mathrm{km}^{-1}$ of carbon dioxide are exempt from a motor vehicle tax

Spain According to the latest act published in June 2014, electric vehicles with mileage between 15 and $40 \mathrm{~km}$ can enjoy a subsidy of 2500 EUR. Pure electric vehicles with mileage of between 40 and $90 \mathrm{~km}$ can enjoy a subsidy of 3500 EUR. Electric vehicles with mileage over $90 \mathrm{~km}$ can receive a subsidy of 5500 EUR. Moreover, older vehicles that are discarded after 10 years can receive a subsidy of 2000 EUR

Denmark Electric automobiles weighing less than $2000 \mathrm{~kg}$ are free from automobile registration tax. However, this regulation does not include hybrid electric automobiles

Sweden New electric automobiles with average energy consumption under $0.37 \mathrm{kWh} \cdot \mathrm{km}^{-1}$ enjoy a 5-year exemption from a motor vehicle tax. Hybrid electric vehicles that meet the definition of a "new green car" can also enjoy similar treatment. Moreover, automobiles with carbon dioxide emissions less than $0.5 \mathrm{~g} \cdot \mathrm{km}^{-1}$ are defined as "super green car premium new cars," which entitle purchasers to a subsidy of 40000 SEK (nearly 4400 EUR). The subsidy number is 5000 cars

Italy Car owners can receive a cash subsidy up to 5000 EUR are exempt from motor vehicle tax for five years, and after five years, they are exempt from part of the motor vehicle tax

UK Car owners, who purchase electric automobiles and plug-in mixed-power automobiles with carbon dioxide emission of $75 \mathrm{~g} \cdot \mathrm{km}^{-1}$, can receive a subsidy of $25 \%$ of the new automobile's price (up to $5000 \mathrm{GBP}$ ). Car owners who purchase light commercial vehicles, such as the electric automobiles with the lowest mileage of 70 miles and plug-in hybrid electric automobiles with the lowest mileage of 10 miles can enjoy a subsidy of $20 \%$ of the automobile's price (up to 8000 GBP)

Switzerland The subsidy cancels the import tariff on electric vehicles, which accounts for $4 \%$ of automobiles' sales prices (excluding valueadded tariff). Twenty-six states in Switzerland have their own legislation rights, so they can each adopt different additional subsidy policies. In Zurich, electric automobiles are exempt from highway fees and hybrid electric automobiles are exempt from half of the highway fees

Greece Electric and hybrid electric vehicles are exempt from registration tax and luxury tax. Electric and hybrid electric vehicles with emission volume of less than $1929 \mathrm{~cm}^{3}$ are exempt from motor vehicle tax. For hybrid electric automobiles with higher emission volumes, half of the common motor vehicle tax is exempt

Luxembourg Pure electric and plug-in hybrid automobiles with carbon dioxide emissions below $60 \mathrm{~g} \cdot \mathrm{km}^{-1} \mathrm{enjoy} \mathrm{a} \mathrm{one-time} \mathrm{subsidy} \mathrm{of} 5000$ EUR if the car owner signs a contract pledging to use electricity from renewable resources

Japan Consumers who purchase electric vehicles can enjoy a subsidy of up to 850000 JPY (about 6200 EUR). In addition, they are exempt from the automobile purchase tax ( $5 \%$ of the purchase price in principle) and automobile weight tax. Japan also decreases the motor vehicle tax substantially 
policies. The Leading the Market Plan introduced by the EU, implements diversified policy tools, which provide innovative guarantees from government procurement, subsidies, legislation, standardization, financial support, and training to create a market environment favorable for innovation. The combinations of various policy tools tend to work in terms of supply, the environment and demand to promote the cultivation and development of emerging industries.

(2) Governments should improve their procurement system and pay attention to SEMs as an innovating force

Most developed countries have already developed government procurement policies and purchased innovative products that SEMs have yet to commercialize to provide an initial market for these enterprises' innovative products. Meanwhile, government procurement departments should provide services and information for SEMs and help them to expand their markets. China should also formulate procurement policies that meet international rules and China's national conditions, and favor SEMs in their procurement policies, to help SMEs participate in the public purchasing market more widely.

(3) Governments should apply comprehensive government subsidy policies and increase subsidies of the demand side.

In the initial development phase in strategic emerging industries, their new products are at a cost disadvantage compared to traditional industries. Users have doubts about the performance and quality of these products. Therefore, offering users' subsidies for products in these emerging industries is a common policy tool observed in various countries as a means to promote the development of emerging industries. For example, the UK encourages "green housing," by exempting and reducing stamp duty to promote the development of solar energy, water cycling equipment, and non-polluting painting industries; Germany provides loans with low interest or no interest for private individuals who install solar energy equipment; Japan offers financial subsidies to consumers who purchase hybrid electric automobiles and other energy-saving and environment friendly automobiles. The subsidy is $50 \%$ of the price gap between the energy-saving and environmentally friendly automobile and a traditional one. The China's government can also learn from these other countries' experiences to offer appropriate subsidies to end users. Besides a common measure of offering financial subsidies to production enterprises, the government could also stimulate market demand and accelerate an industrial development by lowering client purchasing costs.

\section{References}

[1] Guo X H, Li X Y. Energetically develop strategic emerging industries [N]. People's Daily, 2015-12-31 (7). Chinese.

[2] Ning S. Study of public policies [M]. Beijing: Higher Education Press, 2011. Chinese.

[3] Rothwell R, Zegveld W. Reindustrialization and technology [M]. New York: M.E. Sharp, Inc, 1985.
[4] Nemet G F. Demand-pull, technology-push, and government-led incentives for non-incremental technical change [J]. Research Policy, 2009, 38 (5): 700-709.

[5] Zhao X Y, Su J. An analysis framework for public S \& T policies: the perspective of policy tools [J]. Studies in Science of Science, 2007, 25 (1): 52-56. Chinese.

[6] Stefano G D, Gambardella A, Verona G. Technology push and demand pull perspectives in innovation studies: Current findings and future research directions [J]. Research Policy, 2012, 41 (8): 1283-1295.

[7] Peters M, Schneider M, Griesshaber T, et al. The impact of technology-push and demand-pull policies on technical change-Does the locus of policies matter? [J]. Research Policy, 2012, 41 (8): 1296-1308.

[8] Wei J Y, Hong Z S, Xv G N. Reflections and analysis of strategic emerging industries' relevant policies during the "12th Five-year Plan". Report on the development of China's strategic industries (2015) [M]. Beijing: China Science Publishing \& Media Ltd., 2014. Chinese.

[9] Song H F, Mu R P, Ren Z B. Study on correlation between the government procurement policy and the related implemented rules [J]. Studies in Science of Science, 2011, 29 (2): 291-299. Chinese.

[10] Guo A F, Zhou J Z. Practices adopted by US government to support technological innovations and their reference meanings [J]. Science of Scientific and Management of S\&T, 2003, 24 (1): 49-51. Chinese.

[11] Liu J M. Analysis of British government's procurement system and revelation [J]. Public Finance Research, 2013, (3): 69-74. Chinese.

[12] Georghiou L, Edler J, Uyarra E, et al. Policy instruments for public procurement of innovation: Choice, design and assessment [J]. Technoloical Forecasting and Social Change, 2014, 86: 1-12.

[13] Uyarra E, Edler J, Garcia-Estevez J, et al. Barriers to innovation through public procurement: A supplier perspective [J]. Technovation, 2014, 34 (10): 631-645.

[14] Wang C H. On government procurement promoting selfinnovation in China [J]. Studies in Science of Science, 2006, 24 (6): 967-970. Chinese.

[15] Edquist C, Zabala-Iturriagagoitia J M. Pre-commercial procurement: a demand or supply policy instrument in relation to innovation? [J] R \& D Management, 2015, 45 (2): 147-160.

[16] Dufek L. Public Procurement: A panel data approach [J]. Procedia Economics and Finance, 2015, 25: 535-542.

[17] Fan Q, Han M C. The impact of government R\&D subsidy on the performance of national and regional independent innovation - an empirical research based on the panel data of 28 provincial regions [J]. Journal of Industrial Engineering and Engineering Management, 2011, 25 (3): 183-188. Chinese.

[18] Wang S P, Yu M, Yan X F. Main developed countries' new energy policies and their revelations to China $[\mathrm{C}] / /$ Wang Z. Low carbon economy and development of energy enterprises: Literary collection of the fourth China's energy strategy international forum. Beijing: Petroleum industry press, 2009. Chinese.

[19] Mock P, Yang Z F. Driving electrification: A global comparison of fiscal incentive policy for electric vehicles [R/OL]. (2014-05-06) [2016-04-22]. http://www.theicct.org/sites/default/files/publications/ICCT_EV-fiscal-incentives_20140506. 